\title{
The Effect of Snowball Throwing Method Towards the Science Students Learning Result at SD Inpres 5 Doom in Human Panca Idera Materials
}

\author{
$1^{\text {st }}$ Abdul Rachman Tiro ${ }^{1}, 2^{\text {nd }}$ Yannika Nidiasari ${ }^{2}, 3^{\text {rd }}$ Syane Meinar Nunumete ${ }^{3}$ \\ \{updoelrachman@gmail.com ${ }^{1}$, yannikanidiasari@gmail.com ${ }^{2}$ \\ syanenunumete96@gmail.com ${ }^{3}$ \}
}

Uniuversitas Pendidikan Muhammadiyah Sorong, West Papua, Indonesia ${ }^{1,2,3}$

\begin{abstract}
This study aims to determine the effect of the snowball throwing learning model on student learning outcomes in IV students of SD Inpres 5 Doom Classes 2018-2019 Academic Year. The type of research used is quantitative experimental research with preexperimental specifications with the design of one group pre test - post test design. The sample performance was done by purposive sampling technique, with 26 students for the experimental class. The instrument used was a multiple-choice pre-test and post-test test in 20 questions. The results of the analysis of the frequency distribution data in the pre-test and post-test given showed a significant difference because for the students' pre-test the score was more than dengan 59 with a percentage of $69,23 \%$ while for the post-test students got more $70-79$ with a percentage of $34,61 \%$. Validity test The researcher involved 1 (one) expert validator, namely 1 (one) lecturer. Reliability test shows reliability analysis above 0,60 that is 0,721 so it is said to be very reliable on Alpha Cronbach's. The results of the data normality test with Kolmogrov-Smirnov show that the variable data is normally distributed because of the Asymp value. Sig (2-tailed) 0.060 greater than 0.05 . The results of the t-test obtained t--7,936 and t table at the value level Sig. (2-tailed) 0.05 , which is 1.70 ( $t$ count $<\mathrm{t}$ table). This shows that the scientific learning approach influences the mathematics learning outcomes of the fourth grade students, so that the hypothesis is validated.
\end{abstract}

Keywords: Learning model, Snowball throwing, Learning Outcomes, Natural Science.

\section{Introduction}

Education is a learning experience that takes place in the process of learning, skills and habits of groups that are inherited from one generation to the next through research, training, and research. Meanwhile, according to the language department of education, education is the process of changing people through changing and training (Kadir, 2016). Therefore, education is needed to improve the quality of the nation. The importance of education is in line with the contents in the opening of the 1945 Constitution which is said that one of the goals of the State is to educate the life of the nation. Constitution of the Republic of Indonesia No. 23 of 2003 Article 3 is also written: National education is develop capabilities and shape the character and differences of nations that are dignified in order to educate the nation's life, aiming to develop the potential of students to become human beings who believe and fear the Almighty, noble, 
healthy, knowledgeable, capable, creative, independent and becoming a citizen who is democratic and responsible to the country.

The process of organizing education in schools is certainly inseparable from the teacher as an educator and involvment students as learning, it is manifested by the existence of teaching and learning interactions or learning processes. In the context of the implementation, the teacher plans learning activities systematically and it is guided by a set of rules and plans about education that are packaged in the form of a curriculum. One of the problems faced in the world of education in Indonesia is the low quality of student learning outcomes. Many learning theories are applied, but they will not be appropriate if we do not relate learning models to the material that be will delivered (Umar, 2015).

The learning model is inseparable from learning itself. Natural Science Learning in Primary Schools has a very important role, if it is associated with providing provisions for the next level in the future. The goal of Science Education is to make that students master the knowledge, facts, concepts, principles, processes of discovery and have scientific thinking that will benefit students in their own experiences and the surrounding environment. Hamalik, (2013). Explained that learning is a combination that is composed of human, material, equipment and procedures that are influenced each other to achieve learning goals.

The achievement of learning objectives need a learning model. The Snowball Throwing learning model is a cooperative learning model wherein in this learning model, the students are formed into groups which are then the students write a question on a paper and after that the paper is made like a ball. snowball throwing model can be influenced improving the student learning outcomes. This is evidenced by research that is conducted by Kusumawati (2017) with the tittle "Pengaruh Model Pembelajaran Kooperatif dengan Snowball Throwing terhadap hasil belajar IPA pada siswa kelas IV SDN Bondrang Kecamatan Sawo Kabupten Ponorogo".

Based on observations at SD Inpres 5 Doom at the date of 14 April 2018, the use of the lecture method is still inherited in several subjects. The lecturing is provided information verbally by the teacher to the class while the role of the student only listen carefully, and note what the teacher. When the learning process happened not all studens relative can concentrate in a long time, as it is experienced by students, becoming not concentrate when the teacher explaining in front of the class, and their faces also looked lethargic.

The researcher chose the Cooperative learning snowball Throwing model because this model helps students to be more active in the learning process. From the result of observations, the Minimum Completion Criteria in science learning is 60 while students have reach the minimum completeness cure. This is one of the problems in science subject in elementary schools espeatly SD Inpres 5 Doom class IV.

The main marker to know the lack of student learning outcomes in science subject is the loweving of the student learning outcomes during the learning process, the lack of courage to express their opinions, so that the teachers need learning strategies that can improve the student learning outcomes in science subject.

\section{Method}

The research method used is quantitative experimental research with pre-experimental specifications. Experiments are practical ways to learn something by changing the conditions and observing the influence of other things. Experimental research is intended to determine the 
purity of the effect of X on Y. Sugiyono (2008) Quantitative method is an Islamic approach which views reality or it can be classified, concrete, observable and measurable, the relationship of variables is causal where the research data is in the form of numbers and the analysis uses statistics.

The design of this study is included in the experimental research because there are still external variables that influence the formation of independent variables, with this study included in the one group pretest-posttest design to be carried out in a group. In this design the researcher takes the value of the learning outcomes of the students first before doing the treatment. After doing the treatment by doing learning using the snowball throwing learning model in fourth grade science learning, then posttest was given.

This study only has the type of pre-experimental research, where in this study only uses a comparison to analyze accurate data, so in this study the use of variables as follows:

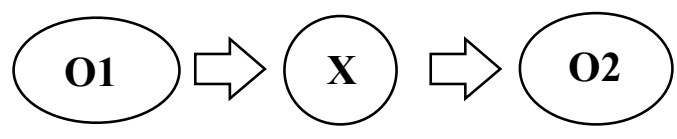

Fig 1. Research Design

Description of the image below:

O1 : value before treatment

$\mathrm{O} 2$ : value after treatment

$\mathrm{X}$ : treatment

The study was carried out at SD Inpres 5 Doom, Sorong City, located at Numberi RK 3 in East Doom. Samples are part of the characteristics possessed by the population. The sample in this study was IVA class students at SD Inpres 5 Doom in the sampling technique. The researcher used Random Sampling techniques in all individuals in the population either individually or together given the same chance to be selected as sample members. The following is a sample list table:

Table 1. Sample list.

\begin{tabular}{ccccc}
\hline \multirow{2}{*}{ School Name } & \multirow{2}{*}{ Class } & \multicolumn{2}{c}{ Student } & \multirow{2}{*}{ Total } \\
\cline { 3 - 4 } & & $\mathbf{M}$ & $\mathbf{F}$ & \\
\hline SD Inpres 5 Doom & IVA & 13 & 17 & 30 \\
\hline
\end{tabular}

Data collection carried out in this study are:

1. Pretest-Posttest Value

2. Documentation

3. Observation

Techniques for analyzing the process of organizing data and sorting data into patterns, categories and basic description units so that they can be found and can be formulated hypothetically as suggested by data (Widiana, 2014). The data analysis technique in this study is to prioritize the $t$ test, the data test must fulfill the analysis requirements test, which is the normality test using the spss application. 


\section{Result And Discussion}

This study used the pre-test and post-test given to the experimental class. Pre test was carried out before being given treatment. The experimental class pre test was conducted on Monday, October 15 2018, and Post test in the experiment class was held on Wednesday October 24, 2018. Post test in the experimental class was carried out shortly after the class received treatment in the form of learning using the Snowball Throwing Learning Model. the description of the frequency distribution of the experimental class pre-test and post test results was as follows:

Table 2. PreTest and Post Test Frequency Distribution of Experimental Class Students.

\begin{tabular}{ccccrc}
\hline \multirow{2}{*}{ Interval Score } & Standard Score & \multicolumn{2}{c}{ Frequency } & \multicolumn{2}{c}{ Percentage } \\
\cline { 3 - 6 } & $\begin{array}{c}\text { Pre } \\
\text { Test }\end{array}$ & $\begin{array}{c}\text { Post } \\
\text { Test }\end{array}$ & Pre Test & $\begin{array}{c}\text { Post } \\
\text { Test }\end{array}$ \\
\hline $90-100$ & $\mathrm{~A}$ & 0 & 0 & $0 \%$ & $0 \%$ \\
\hline $80-89$ & $\mathrm{~B}$ & 0 & 9 & $0 \%$ & $34,61 \%$ \\
\hline $70-79$ & $\mathrm{C}$ & 4 & 5 & $15,38 \%$ & $19,23 \%$ \\
\hline $60-69$ & $\mathrm{D}$ & 4 & 7 & $15,38 \%$ & $26,92 \%$ \\
\hline$\leq 59$ & $\mathrm{E}$ & 18 & 5 & $69,23 \%$ & $19,23 \%$ \\
\hline
\end{tabular}

Pre-Test frequency distribution table for Experimental Class students shows that students who get Standard A and B scores do not exist so the percentage is $0 \%$, standard $\mathrm{C}$ score is 4 with a percentage of $15.38 \%$, standard D score is 4 with a percentage of $15.38 \%$, and $\mathrm{E}$ score is stored 18 with a percentage of $69.23 \%$.

The Post Test frequency distribution table of Experimental Class students shows that students who get an A Score of 0 with a percentage of $0 \%$, Score B amounts to 9 with a percentage of $34.61 \%$, Score $\mathrm{C}$ amounts to 5 with a percentage of $19.23 \%$, Score D amounts to 7 with a percentage $26.92 \%$, and the E score amounts to a percentage of $19.23 \%$.

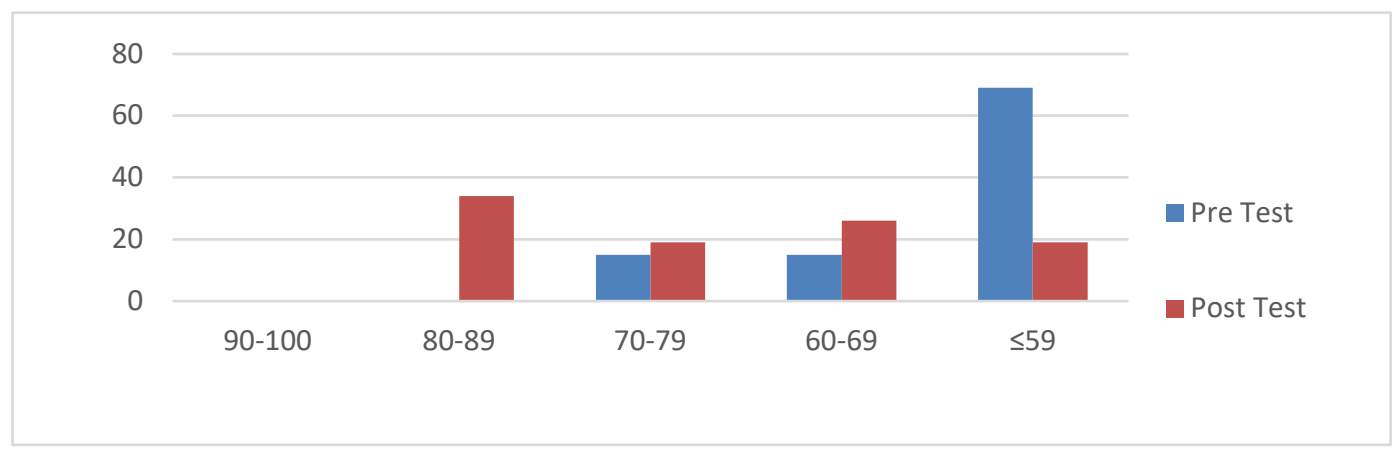

Fig 2. Experimental Class Pre Test and Post Test Diagram

The Experimental Class Pre Test score diagram shows that students who obtained 90-100 grades did not exist, 80-89 scores did not exist, 70-79 scores amounted to 4 students, 60-69 were 4 students, and the value of 59 was 18 students. 
Post Test score class of Experimental Class shows that students who get 90-100 scores are 0 students, $80-89$ are 9 students, $70-79$ are 5 students, 60-69 are 7 students, and grades $\leq 59$ five students.

Based on Image 2, it can be seen that there is a very significant effect after using the snowball learning model, the ability of students to increase compared to using conventional methods

Table 3. Experimental Class Pre Test

\section{Statistics}

\begin{tabular}{lrr}
\hline VAR00001 & \\
\hline \multirow{2}{*}{$\mathrm{N}$} & Valid & 26 \\
\cline { 2 - 3 } & Missing & 0 \\
\hline Mean & 49.62 \\
\hline Median & 50.00 \\
\hline Mode & 35 \\
\hline Std. Deviation & 14.895 \\
\hline Minimum & 25 \\
\hline Maximum & 75 \\
\hline
\end{tabular}

Table 4. Experimental Class Post Test

\section{Statistics}

\begin{tabular}{lrr} 
VAR00001 & \\
\hline \multirow{2}{*}{$\mathrm{N}$} & Valid & 26 \\
\cline { 2 - 3 } & Missing & 0 \\
\hline Mean & 68.48 \\
\hline Median & 70.00 \\
\hline Mode & 80 \\
\hline Std. Deviation & 11.642 \\
\hline Minimum & 45 \\
\hline Maximum & 85 \\
\hline
\end{tabular}

Based on the table 3 and 4 it can be seen that the number of valid data is 26 , while the rejected or missing is 0 which means that the overall data from the Pre Test and Post Test Test Experiments used for the analysis process are valid. This means that data can be processed later.

The normality test is used to measure whether the data has a normal distribution or not. In this case the data normality test is carried out using the Kolmogrov-Smirnov approach.

The Kolmogrov-Smirnov test is one of the nonparametric statistical tests that is used to determine the distribution of data used in research with normal distribution or not. The following is the display of the Kolmogrov-Smirnov test results with the help of SPSS 20 
Table 5. Normality Test Results.

One-Sample Kolmogorov-Smirnov Test

\begin{tabular}{|ll|r|}
\hline & & \multicolumn{2}{|c|}{ Postes } \\
\hline Normal Parameters & & 26 \\
& Mean & 68.46 \\
& Std. Deviation & 11.642 \\
Most Extreme Differences & Absolute & .185 \\
& Positive & .122 \\
Kolmogorov-Smirnov Z & Negative & -.185 \\
Asymp. Sig. (2-tailed) & & .945 \\
\hline
\end{tabular}

The data normality test results with Kolmogrov-Smirnov significant level of 0.05 with decision making if a significant value is less than 0.05 , the data distribution is not normal and if a significant value is greater than 0.05 then the data distribution is normal. Based on the table the results of the normality test. it can be concluded that the variable data is normally distributed because of the value of Asymp. Sig. (2-tailed) 0.060 greater than 0.05 .

Table 6. $\mathrm{T}$ Test Results

Paired Samples Statistics

\begin{tabular}{|rl|r|r|r|r|}
\hline & & \multicolumn{1}{|c|}{ Mean } & \multicolumn{1}{c|}{ N } & \multicolumn{1}{c|}{ Std. Deviation } & Std. Error Mean \\
\hline \multirow{2}{*}{ Pair 1 } & Pretest & 49.62 & 26 & 14.895 & 2.921 \\
& Postest & 68.46 & 26 & 11.642 & 2.283 \\
\hline
\end{tabular}

Table 6 shows the summary results of descriptive statistics from both samples or Pre Test and Post Test data. The mean is the average value of a data, for the Pre Test is 49.62 and for the Post Test is 68.46. N is the number of samples used each of 26 samples. Std. Deviation on Pre Test is 104,895 and for Post Test 11,642. Std. The mean error on the Pre Test is 2.921 and for the Post Test 2,283.

\begin{tabular}{|c|c|c|c|c|c|c|c|c|c|}
\hline & \multicolumn{5}{|c|}{ Paired Differences } & \multirow[t]{3}{*}{$\mathbf{T}$} & \multirow[t]{3}{*}{ Df } & \multirow{3}{*}{$\begin{array}{l}\text { Sig. } \\
\text { (2-tail } \\
\text { ed) }\end{array}$} \\
\hline & & \multirow[t]{2}{*}{ Mean } & \multirow[t]{2}{*}{$\begin{array}{c}\text { Std. } \\
\text { Deviatio } \\
n\end{array}$} & \multirow[t]{2}{*}{$\begin{array}{l}\text { Std. Error } \\
\text { Mean }\end{array}$} & \multicolumn{2}{|c|}{$\begin{array}{l}95 \% \text { Confidence } \\
\text { Interval of the } \\
\text { Difference }\end{array}$} & & & \\
\hline & & & & & Lower & Upper & & & \\
\hline Pair 1 & $\begin{array}{l}\text { Pret } \\
\text { est } \\
- \\
\text { Pos } \\
\text { tes } \\
t\end{array}$ & -18.846 & 12.108 & 2.375 & -23.737 & -13.955 & -7.936 & 25 & .000 \\
\hline
\end{tabular}

Fig 3. Resut

It is known that the results of the $t$ test are obtained $t-7.936$ and $t$ table at 1.70 (tcount $<$ ttable), it can be concluded that there are significant significant differences between the learning outcomes of science in the Pre Test and Post Test data. 


\section{Conclusion}

Based on the results of the analysis of collected data and processing analysis using the SPSS 20 application, it can be seen that: Snowball Throwing Learning Model influences the science learning outcomes of fourth grade students, so the hypothesis can be verified, this can be seen from the Pre Test data and Post Test Results showing differences significant, because the results of the Post Test showed that more students scored $>59$ so that the percentage was $80.76 \%$ while the 5 students scored $<59$ so the percentage was $19.23 \%$ compared to the results of the Pre Test showing more students scored $<59$ so the percentage was $69,23 \%$. The results of the $t$ test were obtained $t-7.936$ and $t$ table at the level of Sig. (2-tailed) 0.05 which is equal to 1.70 ( $t$ count $<\mathrm{t}$ table), it can be concluded that there is a significant significant effect between the mathematics learning outcomes on the Pre Test and Post Test data.

\section{REFERENCES}

[1] Lamudin, Ali. (2014) Pengaruh Penerapan Model Pembelajaran Snowball Throwing Terhadap Hasil BelajarMatematika Siswa Dengan Pokok BahasanRelasi Dan Fungsi. Jurnal Kependidikan Dasar Islam Berbasis Sains, 1-10.

[2] Indriani, Nia. (2017) Meningkatkan Percaya Diri Siswa Melalui Model Snowball Throwing Dalam Pembelajaran IPA Pada Siswa Kelas IV Di SD Negeri 111 Muara Burian. Jurnal Kependidkan Dasar IPA Berbasis Sains, 1-14.

[3] Kusumawati, Naniek. (2017) Pengaruh Model Pembelajaran Kooperatif dengan Snowball Throwing Terhadap Hasil Belajar IPA Pada Siswa Kelas IV SDN Bondrang Kecamatan Sawoo Kabupaten Ponorogo: Jurnal Kependidikan Dasar Berbasis Sains, 1-12.

[4] Widiana. (2014) Pengaruh Model Pembelajaran Snowball Throwing Terhadap Hasil Belajar IPA Dengan Kovariabel Kemampuan Berpikir Kreaktif Siswa Kelas IV SD. Jurnal Mimbar PGSD, $1-12$.

[5] Hamalik, Oemar. 2013. Proses belajar Mengajar. Jakarta: PT. Bumi Aksara

[6] Kadir, (2016) Gagasan dan Cita Wujudkan Pendidikan dan Bangsa Indonesia Yang Beradab. Jakarta: Gremedia Pustaka Utama.

[7] Umar, Tirtaraharjda (2015) Pendidikan dan Pembelajaran, Jakarta: Gremedia Pustaka Utama. 